Wright State University

CORE Scholar

$1-2010$

\title{
Cellular and Molecular Dissection of Pluripotent Adult Somatic Stem Cells in Planarians
}

\author{
Norito Shibata \\ Labib Rouhana \\ Wright State University - Main Campus, labib.rouhana@wright.edu \\ Kiyokazu Agata
}

Follow this and additional works at: https://corescholar.libraries.wright.edu/biology

Part of the Biology Commons, Medical Sciences Commons, and the Systems Biology Commons

\section{Repository Citation}

Shibata, N., Rouhana, L., \& Agata, K. (2010). Cellular and Molecular Dissection of Pluripotent Adult Somatic Stem Cells in Planarians. Development, Growth and Differentiation, 52 (1), 27-41.

https://corescholar.libraries.wright.edu/biology/328

This Article is brought to you for free and open access by the Biological Sciences at CORE Scholar. It has been accepted for inclusion in Biological Sciences Faculty Publications by an authorized administrator of CORE Scholar. For more information, please contact library-corescholar@wright.edu. 


\title{
Review Article
}

\section{Cellular and molecular dissection of pluripotent adult somatic stem cells in planarians}

\author{
Norito Shibata, ${ }^{1 *}$ Labib Rouhana ${ }^{2}$ and Kiyokazu Agata ${ }^{2}$ \\ ${ }^{1}$ Global COE Program, Division of Biological Science, Graduate School of Science, Kyoto University, and ${ }^{2}$ Department of \\ Biophysics, Graduate School of Science, Kyoto University, Kitashirakawa-Oiwake, Sakyo-ku, Kyoto 606-8502, Japan
}

\begin{abstract}
Freshwater planarians, Plathelminthes, have been an intriguing model animal of regeneration studies for more than 100 years. Their robust regenerative ability is one of asexual reproductive capacity, in which complete animals develop from tiny body fragments within a week. Pluripotent adult somatic stem cells, called neoblasts, assure this regenerative ability. Neoblasts give rise to not only all types of somatic cells, but also germline cells. During the last decade, several experimental techniques for the analysis of planarian neoblasts at the molecular level, such as in situ hybridization, RNAi and fluorescence activated cell sorting, have been established. Moreover, information about genes involved in maintenance and differentiation of neoblasts has been accumulated. One of the molecular features of neoblasts is the expression of many RNA regulators, which are involved in germline development in other animals, such as vasa and piwi family genes. In this review, we introduce physiological and molecular features of the neoblast, and discuss how germline genes regulate planarian neoblasts and what differences exist between neoblasts and germline cells.
\end{abstract}

Key words: adult somatic stem cell, germline-specific genes, neoblast, planarian, pluripotency.

\section{Introduction}

Adult somatic stem cells (ASCs) are maintained by self-renewal and differentiate into function-specific cells in order to replace dead and injured cells in various tissues. Due to their scientific appeal and potential medical application, stem cells in mammalian tissues are the best documented ASCs. However, ASCs exist in many species belonging to various phyla (Sánchez Alvarado \& Kang 2005; Agata et al. 2006; Bosch 2008). Whereas the fundamental cellular and molecular bases of these ASCs are still poorly understood, the accumulation of knowledge about ASCs from diverse species may give us a good opportunity not only to understand the common principles of stem cells, but also guide their use in regenerative medicine.

Freshwater planarians, turbellarians belonging to phylum Plathelminthes, are known to possess ASCs

${ }^{*}$ Author to whom all correspondence should be addressed.

Email: shiba@mdb.biophys.kyoto-u.ac.jp

Received 21 August 2009; revised 12 November 2009; accepted 13 November 2009.

(c) 2010 The Authors

Journal compilation @ 2010 Japanese Society of Developmental Biologists called neoblasts (Baguñà 1981). Dugesia japonica is a common planarian species in Japan. It measures up to $2 \mathrm{~cm}$ in size and has clearly defined organs such as a well-organized brain with different types of neurons, a pharynx for feeding and excretion in the central portion of its body, and an intestine composed of three main branches (Fig. 1; Umesono et al. 1997; Agata et al. 1998; Kobayashi et al. 1998; Umesono et al. 1999; Cebria et al. 2002b,c; Nishimura et al. 2007a,b; Umesono \& Agata 2009). Despite their complex body structure, planarians have robust regenerative ability, in other words, asexual reproduction ability. Almost any small fragment from anywhere behind the eyes of the planarian body can regenerate and develop into a complete animal, with a functional brain, within a week after amputation (Agata et al. 2003; Rossi et al. 2008; Umesono \& Agata 2009). Planarians' remarkable ability to regenerate is strictly dependent on their neoblasts (Baguñà et al. 1989; Agata \& Watanabe 1999; Newmark \& Sánchez Alvarado 2002; Salò \& Baguñà 2002; Agata et al. 2003, 2006; Reddien \& Sánchez Alvarado 2004; Sánchez Alvarado 2006, 2007; Rossi et al. 2008). During regeneration, the neoblasts give rise to all types of cells, not only somatic but also germline cells (Sato et al. 2006; Handberg-Thorsager \& Salò 

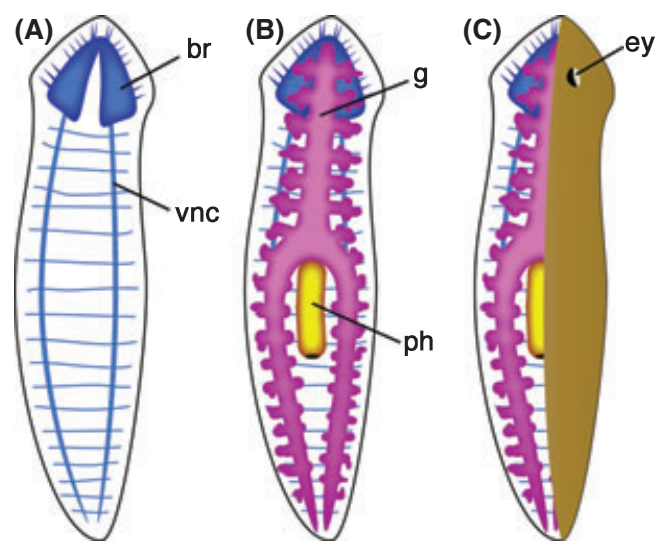

Fig. 1. Schematic illustration of main organs of Dugesia japonica. (A) Nervous system. A brain (br) exists in the anterior region of the ventral side. A pair of ventral nerve cords (vnc) extends from the brain to the tail tip. (B) Digestive organ. A pharynx (ph) exists in the central portion of the body and acts as a mouth and anus. A gut (g) occupies almost the entire mesenchymal space and delivers nutrition instead of a blood circulatory system. (C) A pair of eyes (ey) is observed in the head region of the dorsal side.

2007; Wang et al. 2007). Neoblasts also supply all cells in intact individuals during the 'wear and tear' of tissue homeostasis (Newmark \& Sánchez Alvarado 2000).

Initially, neoblasts were defined by their morphological features, based on electron microscopy (Pedersen 1959; Morita 1967; Hori 1992). Ten years ago, we identified DjvlgA (vasa-like gene A), the first planarian gene identified with neoblast-enriched expression (Shibata et al. 1999). Since then, a considerable number of genes have been shown to be expressed in the neoblasts and to function in neoblast regulation in several planarian species (Salvetti et al. 2000; Ogawa et al. 2002; Sánchez Alvarado et al. 2002; Orii et al. 2005; Salvetti et al. 2005; Reddien et al. 2005a,b; Guo et al. 2006; Sato et al. 2006; Handberg-Thorsager \& Salò 2007; Oviedo \& Levin 2007; Rossi et al. 2007; Wang et al. 2007; Yoshida-Kashikawa et al. 2007; Palakodeti et al. 2008; Solana et al., 2009). Furthermore, the establishment of a stem cell purification method, based on fluorescence activated cell sorting, has enabled us to analyze the cellular aspects of neoblasts in greater detail (Hayashi et al. 2006; Higuchi et al. 2007). Thus, much knowledge about the cellular and molecular bases of neoblasts has been accumulated during the past decade. Here, we introduce what is currently known about the cellular and molecular features of the neoblasts, and discuss the molecular mechanisms that regulate and maintain the pluripotency of neoblasts.

\section{Morphological and physical features of the neoblasts}

In the planarian, neoblasts ( $30 \%$ of total cells) can be observed throughout the entire mesenchymal space of the body with the exception of the pharyngeal region and the region anterior to the eyes (Fig. 1; Baguñà et al. 1989; Newmark \& Sánchez Alvarado 2000). This distribution pattern corresponds to the regenerative ability of $D$. japonica, in which complete regeneration can be achieved from body fragments anywhere posterior to the eyes except for the pharynx.

Neoblasts are the only cell population possessing continual proliferative ability in planarians. Newmark \& Sánchez Alvarado (2000) were able to visualize mitotic cells using BrdU in a related species, Schmidtea mediterranea. Only neoblasts incorporate BrdU immediately after treatment, and almost all neoblasts incorporate BrdU within 2 days of injection (Kang \& Sánchez Alvarado 2009). Some BrdU-incorporating cells are also visualized with anti-phosphorylated histone $\mathrm{H} 3$ antibody (pH3), an indicator of mitotic (M-phase) cells (Newmark \& Sánchez Alvarado 2000). $D$. japonica neoblasts also incorporate BrdU specifically, and can be labeled with anti-pH3 antibodies (Fig. 2A-D; Inoue et al. 2007; Yoshida-Kashikawa et al. 2007; Higuchi et al. 2008). Genes related to the process of DNA replication such as minichromosome maintenance 2 homologue, DjMCM2, or proliferating cell nuclear antigen, Djpcna, are also specifically expressed in the neoblasts (Salvetti et al. 2000; Orii et al. 2005). The cell cycle of neoblasts is accelerated by feeding or amputation of the animals (Baguñà 1974, 1975; Kang \& Sánchez Alvarado 2009), which probably indicates the expeditious supplying of cells that accompanies regeneration and growth of an individual.

Classically, electron microscopic observations revealed the typical morphological features of neoblasts. Neoblasts are approximately $10 \mu \mathrm{m}$ in size, of round or ovoid shape, and show a high nucleus/cytoplasm ratio (Fig. 2E). No obvious organelles other than free ribosomes and mitochondria are observed in their scanty cytoplasm (Pedersen 1959). An unambiguous structural feature of neoblasts is cytoplasmic chromatoid bodies. Chromatoid bodies are observed as are round, electron-dense structures that are not surrounded by a membrane (Fig. 2E; Morita 1967; Coward 1974; Hori 1982). These structures show sensitivity to Ribonuclease $A$ and actinomycin-D treatment (Hori 1982; Auladell et al. 1993), indicating that these structures are ribonucleoprotein (RNP) complexes. The size and number of chromatoid bodies decreases during the neoblast cell differentiation process (Hori 
Fig. 2. Distribution pattern and morphology of neoblasts in the planarian Dugesia japonica. (A) Hoechst staining (blue) shows the main organs. A pair of eyes (ey) and a brain (br) exist in the head region. The pharynx (ph) occupies the central portion of the body. (B) Expression of DjPiwiA (green) and anti-phospho-Histone $\mathrm{H} 3$ antibody staining (magenta) indicates the distribution pattern of neoblasts. Neoblasts are localized throughout the mesenchymal space of the entire body except the head and pharyngeal region. (C) Merged image of $A$ and B. Scale bar is $500 \mu \mathrm{m}$. (D) Antiphospho-Histone $\mathrm{H} 3$ antibody staining (magenta) indicates the mitotic ability of neoblasts, which are identified by expression of DjpiwiA (green). Scale bar is $10 \mu \mathrm{m}$. (E) Ultrastructure of the neoblast observed by transmission electron microscopy. Arrowheads indicate chromatoid bodies in the cytoplasm of neoblasts. Highermagnification view of the chromatoid body is shown in the box. Scale bar is $2 \mu \mathrm{m}$.
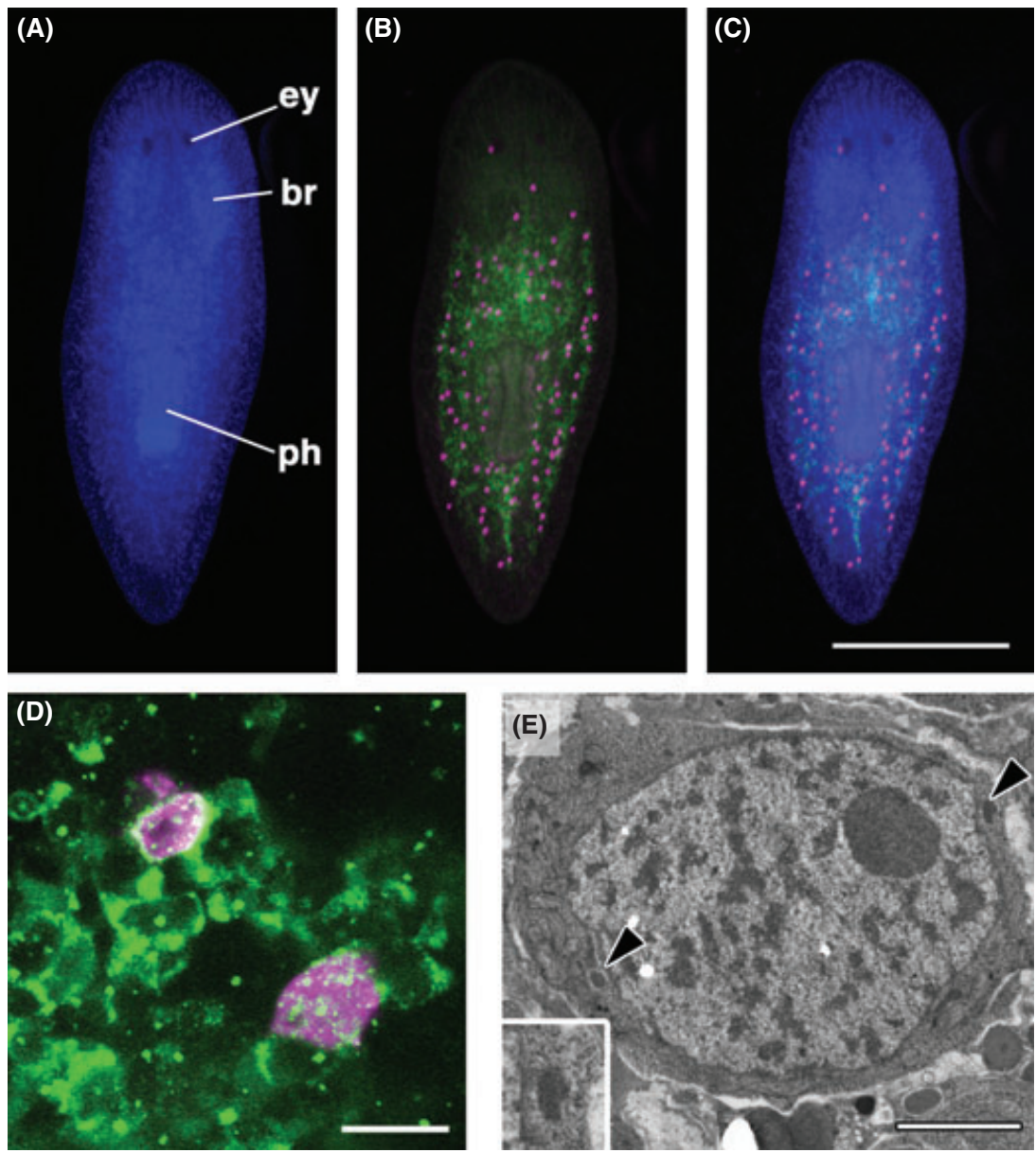

1982, 1997), suggesting that these structures may be involved in neoblast maintenance.

\section{Pluripotency of the neoblasts}

Although there is no definitive experimental evidence for the pluripotency of neoblasts, which could be proved by clonal cell culture or single cell transplantation, multiple experiments support the notion of the pluripotency of the neoblasts. Planarians irradiated with the appropriate dose of $\mathrm{X}$ - or gamma-rays lose their regenerative ability due to the specific elimination of neoblasts (Wolff \& Dubois 1948). Planarians with an irradiated anterior half of the body can regenerate a head due to migration of neoblasts from a nonirradiated posterior part (Wolff \& Dubois 1948). A population of stem cells, isolated via size fractionation, can restore the regenerative ability of irradiated planarians (Baguñà et al.; Kobayashi et al. 2008). Furthermore, planarian regeneration proceeds in an intercalative, position-dependent manner (Agata et al. 2003), and superfluous body structures, such as a brain or pharynx, are induced when a head fragment is transplanted into the tail region of planarians (Kobayashi et al. 1999). Finally, when a small piece of the middle region of the body is grafted at the original position but in the dorsoventral-reversed orientation, ectopic structures such as a head or tail are frequently formed at the grafted position (Kato et al. 1999, 2001). These observations and the fact that almost any tiny fragment of the planarian body can regenerate an entire organism (Morgan 1898) show not only that the neoblasts can respond to changes of their environment, but also that neoblasts can give rise to all types of cells.

\section{Heterogeneity of the neoblasts}

We developed a fluorescence activated cell sorting (FACS) method for cells of $D$. japonica, based on Hoechst staining for DNA content and Calcein-AM staining for cell size (Hayashi et al. 2006). Comparison of cell sorting profiles of intact and $X$-ray irradiated planarians revealed two different $X$-ray sensitive cell fractions: $X 1$ and $X 2$ (Fig. 3A,B). The $X 1$ fraction is composed of $S$ to M-phase neoblasts, as confirmed by higher DNA 


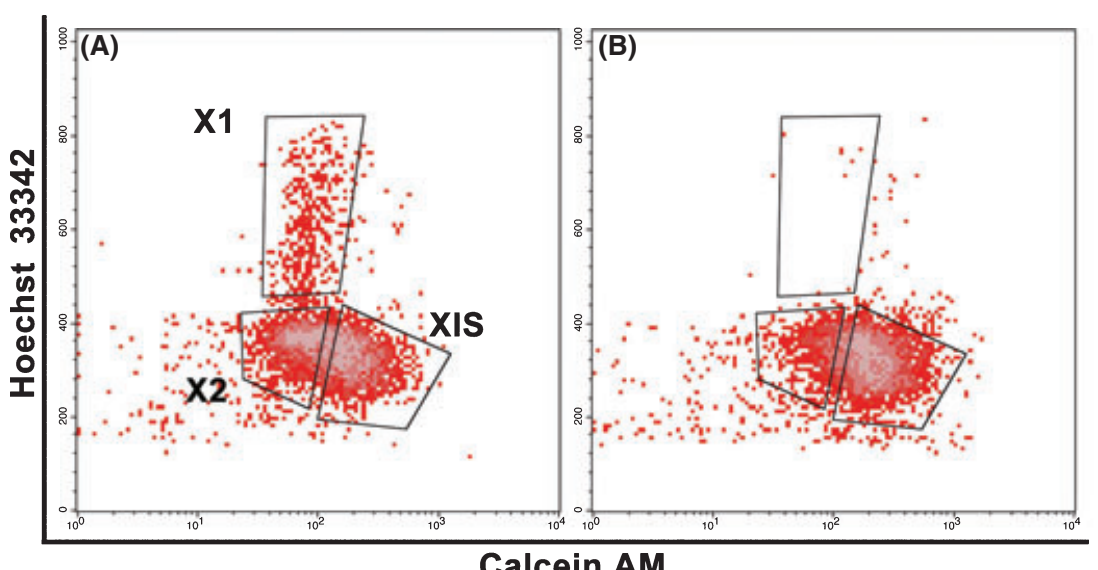

Calcein AM
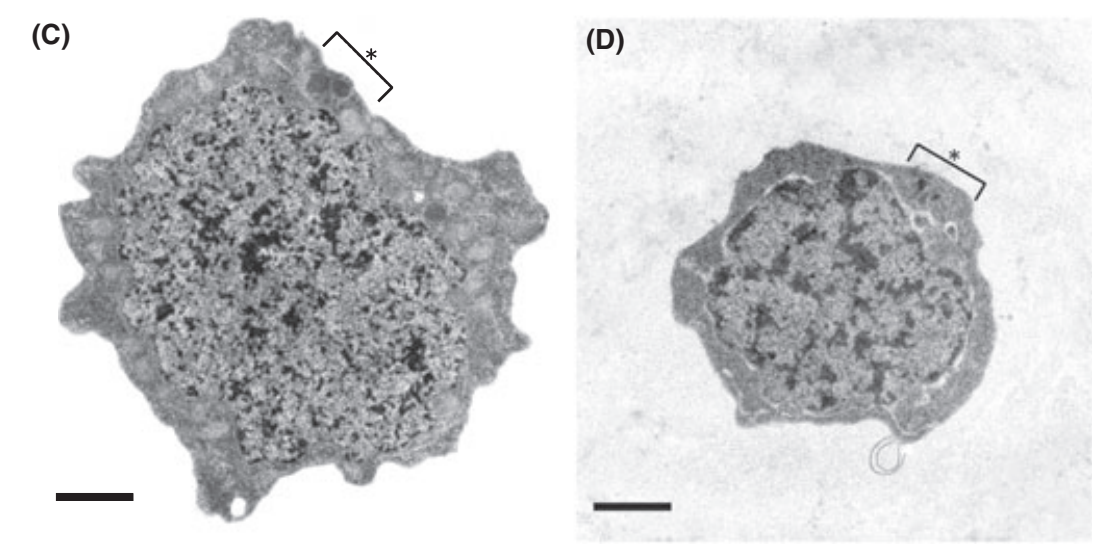

Fig. 3. Cell sorting profiles of intact and $\mathrm{X}$-ray-irradiated planarians by fluorescence activated cell sorting (FACS) identifies two types neoblasts with different morphologies. (A) Cell sorting profile of intact planarians. Cells are separated into three fractions, X1, X2 and XIS (B) Cell sorting profile of $X$-ray-irradiated planarians. The majority of cells in the X1 fraction and about half of the cells in the $\mathrm{X} 2$ fraction disappear, identifying these cells as X-raysensitive neoblasts. (C) Morphology of Type 1 cells (typical neoblasts) in the X1 fraction (Higuchi et al. 2007). These cells have scanty cytoplasm, chromatoid bodies and nuclei rich in euchromatin. (D) Morphology of Type 2 cells preferentially observed in the X2 fraction. Chromatoid bodies and scanty cytoplasm are also observed, but developed heterochromatin is observed in the nuclei of Type 2 cells. Type 2 cells are smaller than Type 1 cells. Scale bar is $1 \mu \mathrm{m}$. Asterisk indicates location of some of the chromatoid bodies. (C and D) are modified from Higuchi et al. (2007). content and gene expression profiles (Fig. 3A; Hayashi et al. 2006). About half of the cells sorted into the X2 fraction are G1 neoblasts, and the remaining half of the $\mathrm{X} 2$ fraction and most of the $\mathrm{X}$-insensitive fraction (XIS) are differentiated cells showing tolerance to irradiation (Fig. 3A,B).

Detailed analysis of cells collected by FACS revealed heterogeneity in the neoblast population (Higuchi et al. 2007). Cells were categorized into one of three types according to their morphological features: stem cell, differentiating cell, or differentiated cell. Surprisingly, a considerable number of differentiating cells were observed in the $\mathrm{X} 1$ fraction (17\% of $\mathrm{X} 1$ cells; Higuchi et al. 2007). Neoblasts are thought to stop proliferation after commitment, but this finding indicates that some differentiating cells possess the ability to divide. Heterogeneity among morphologically classified stem cells was also reported, and stem cells classified as "Type B", which here we rename "Type 2" cells, exist in the X2 fraction (Fig. 3D; Higuchi et al. 2007), and stem cells smaller in size than typical neoblasts (originally "Type A" stem cells, which we rename "Type 1" stem cells, here). Type 2 cells also have a smaller number of chromatoid bodies, and contain more tightly condensed heterochromatin (Fig. 3C,D). It is possible to consider Type 2 stem cells as typical neoblasts in a different phase of the cell cycle from Type 1 neoblasts (Gurley \& Sánchez Alvarado 2008). However, the majority of stem cells in the X2 fraction are definitely Type 1 stem cells, which suggests that Type 2 cells may belong to a distinctly new class of planarian stem cells.

Recently, the existence of a highly dormant state of hematopoietic stem cells has been reported (Wilson et al. 2008). In many cases, true stem cells have shown a state of slow cell cycle progression (Fuchs 2009), suggesting that Type 2 stem cells may be slow-cycling stem cells. Type 2 cells may also be descendents of Type 1 stem cells on their way to commitment, which is comparable to reported observations in S. mediterranea (Eisenhoffer et al. 2008). Gene expression analysis in D. japonica has also revealed heterogeneity of the neoblasts (Rossi et al. 2006, 2007; Sato et al. 2006; Salvetti et al. 2009). It seems that, after all, the planarian stem cell system is a more complex system than the homogenous cell population of the neoblasts they were previously thought likely to be. 
Fig. 4. Subcellular localization of DjCBC-1 and DjPiwiA protein in neoblasts. (A) Double immunohistochemistry using anti-DjCBC-1 antibody (green) and anti-DjPiwiA antibody (magenta). Both proteins are detected in the cytoplasm of neoblasts. Scale bar is $10 \mu \mathrm{m}$. (B) Subscellular localization of DjCBC-1 protein. Punctate signals (arrows) are observed in the cytoplasm of the neoblast. (C) Subcellular distribution of DjPiwiA protein. DjPiwiA protein is observed widely diffused in the cytoplasm of neoblasts. (D) Merged image of $\mathrm{B}$ and C. DjCBC-1 and DjPiwiA protein localization does not completely overlap. Scale bar is $5 \mu \mathrm{m}$.
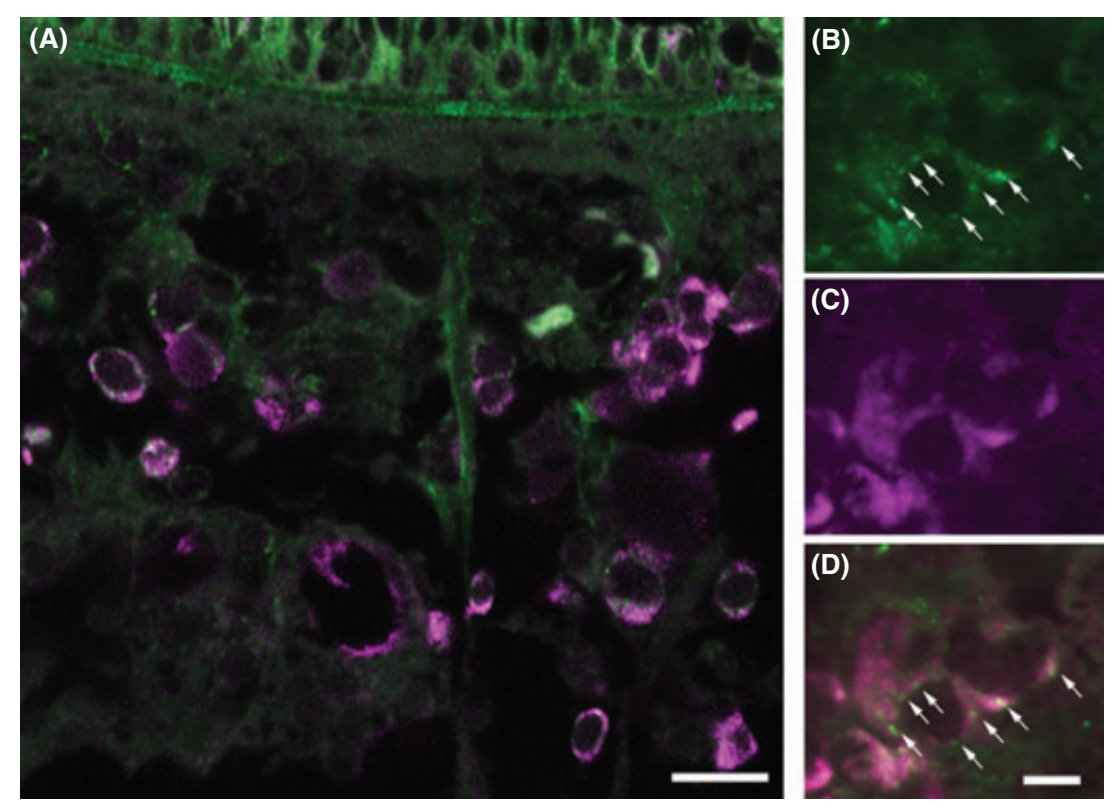

\section{Molecular features of the neoblasts}

\section{Components of the chromatoid bodies}

As mentioned above, a distinguishable characteristic of the neoblasts is the presence of chromatoid bodies. The morphological features of chromatoid bodies in planarian ASCs resemble those of well-documented RNP granules in the cytoplasm of germ cells of several animals (Seydoux \& Braun 2006), implying commonality of the protein and RNA components between such cytoplasmic structures. Thus far, only two chromatoid body protein components have been identified in planarian neoblasts: DjCBC-1 and SpolTud-1 (YoshidaKashikawa et al. 2007; Solana et al. 2009). Both of these proteins are homologues of components of germline granules in other organisms. We identified chromatoid body component-1 (Djcbc-1), which is a gene in D. japonica that codes for a protein about $70 \%$ identical to members of the RCK/p54/Me31b/ Dhh1p family of DEAD box RNA helicases (YoshidaKashikawa et al. 2007). DjCBC-1 protein is observed in the chromatoid bodies (Fig. 4A,B). Expression of tudor homologues in planarian neoblasts has been reported by us and others (Fig. 5A; Yoshida-Kashikawa et al. 2007; Solana et al. 2009). A Tudor-domain-containing protein from Schmidtea polychroa was also shown to localize to chromatoid bodies, and to be required for long-term stem cell self-renewal (Solana et al. 2009). Another component is nanos mRNA, which is detected in chromatoid bodies of germline precursor cells described below (Sato et al. 2006).
Piwi and interacting small RNAs in the neoblasts

The Piwi sub-family of Argonaute proteins, and small non-coding Piwi-interacting RNAs (piRNA) are essential for germline development, germline stem cell renewal, epigenetic regulation, and repression of transposable elements (Cox et al. 1998; Aravin et al. 2007; Girard \& Hannon 2007; Yin \& Lin 2007; Siomi et al. 2008; Malone \& Hannon 2009). Piwi-deficient animals show severe defects in germline stem cell maintenance and germ cell differentiation (Lin \& Spradling 1997; Cox et al. 1998; Kuramochi-Miyagawa et al. 2004; Carmell et al. 2007). piwi homologues in planarians, Smedwi-1, -2 and -3 (or Djpiwi $A, B$, and $C$, respectively), are exclusively or preferentially expressed in neoblasts (Fig. 2A; Reddien et al. 2005b; Rossi et al. 2007; YoshidaKashikawa et al. 2007; Palakodeti et al. 2008; Hayashi et al. in this issue), and are essential for precise cell differentiation and/or stem cell maintenance (Reddien et al. 2005b; Palakodeti et al. 2008). Comprehensive sequence analysis revealed enrichment of piRNAs in neoblasts of S. mediterranea, of which $32 \%$ mapped to transposons (Friedländer et al. 2009), suggesting that Piwis prevent transposable element activity in the neoblasts of planarians. Piwi family proteins localize to germline granules in fly and mouse (Seydoux \& Braun 2006; Kotaja \& Sassone-Corsi 2007). Although both DjCBC-1 and DjPiwiA protein are present in the neoblasts (Fig. 4A), DjPiwiA does not seem to co-localize with DjCBC-1 in chromatoid bodies in D. japonica (Fig. 4B-D). 

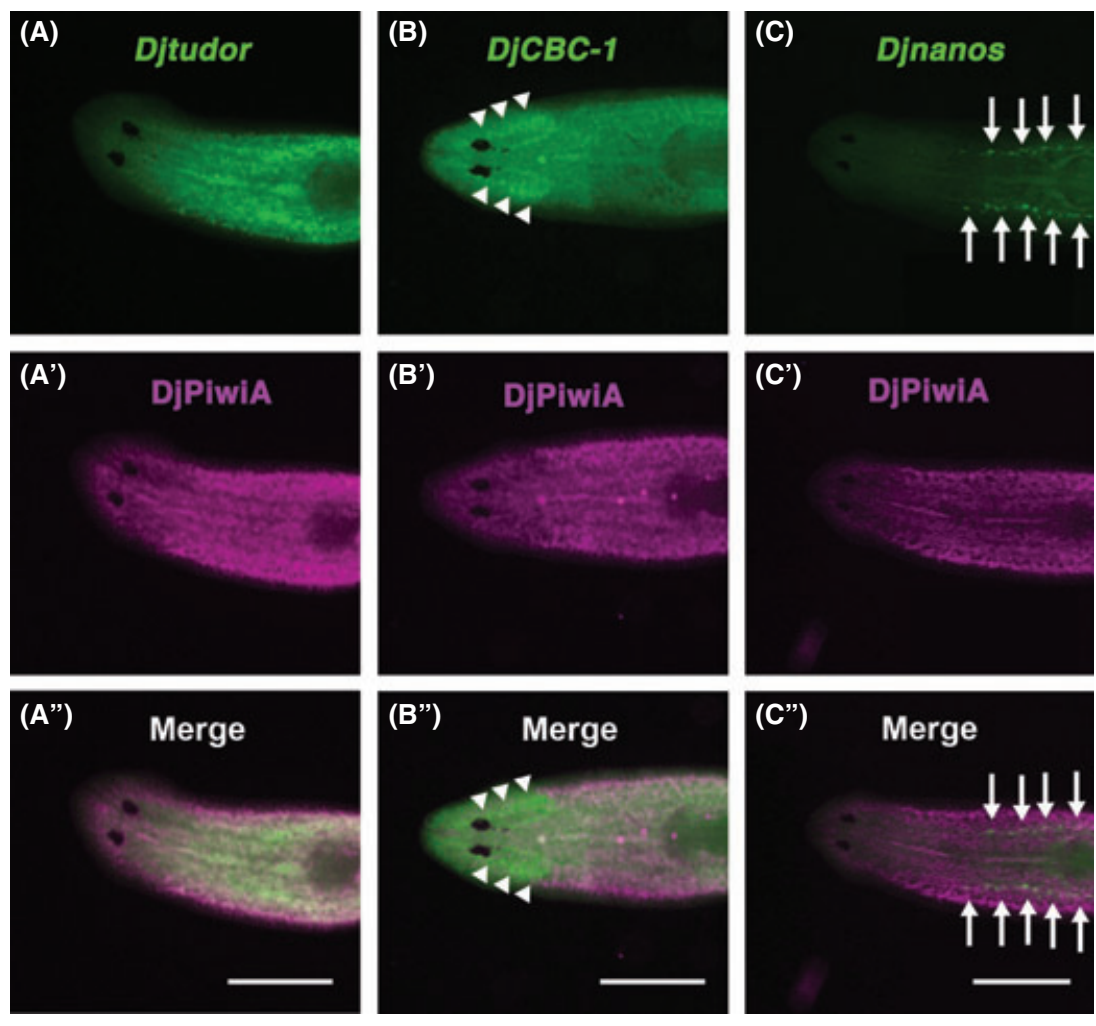
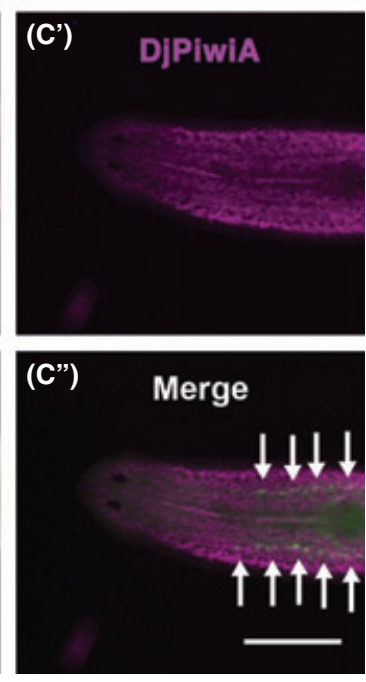

Fig. 5. Expression pattern of Type A genes, Type B genes and Djnos. (A) Expression pattern of Type A gene, Djtudor (green). Expression of Type A genes is only detected in neoblasts. (A') Anti-DjPiwiA antibody staining in the same sample (magenta). (A') Merged image of $A$ and $A^{\prime}$. Almost of all of the neoblasts co-express DjPiwiA and Djtudor. (B) Expression pattern of Type B gene, Djcbc-1. Arrowheads indicate brain. (B') Anti-DjPiwiA antibody staining in the same sample. (B') Merged image of B and B'. Type $\mathrm{B}$ genes' expression is detected in both neoblasts and brain cells. (C) Expression pattern of nanos in asexual planarians. Dorso-lateral cell cluster expressing Djnos (arrows). (C') AntiDjPiwiA antibody staining in the same sample. (C') Merged image of $\mathrm{C}$ and $C^{\prime}$. Only a subpopulation of neoblasts express Djnos. Bars, $500 \mu \mathrm{m}$.

\section{Expression of germline-specific genes in the planarian} ASCS

As mentioned in the Introduction, the first gene shown to be expressed in planarian neoblasts was vasa-like gene A. DjvlgA codes for proteins with sequence similarity to Vasa, a DEAD box RNA helicase component of germ granules in other animals (Lasko \& Ashburner 1988; Fujiwara et al. 1994; Yoon et al. 1997; Shibata et al. 1999). DjvlgA and DjvigB are expressed in mature testes and ovaries of sexual planarians. DjvigA, however, is also expressed in neoblasts and differentiating blastema cells, suggesting that DjvigA may be involved in commitment and differentiation of neoblasts (Shibata et al. 1999; Newmark \& Sánchez Alvarado 2002). In fact, DjvigA and DjvigB belong to the PL10/DDX3 subfamily of helicases, which is a subfamily of DEAD box proteins, closely related to vasa (Mochizuki et al. 2001). An actual member of the vasa subfamily of DEAD box proteins has been identified in the planarian Dugesia dorotocephala (Mochizuki et al. 2001), and its orthologue is also present in our $D$. japonica expressed sequence tag (EST) database.

Homologues of several proteins involved in posttranscriptional regulation in the germline of different organisms have since been shown to be relevant to planarian neoblasts. Djpum, a member of the PUF
(Pum and FBF)-domain family of proteins required for the maintenance and function of germline cells in flies and nematodes (Lin \& Spradling 1997; Parisi \& Lin 1999; Crittenden et al. 2002; Wickens et al. 2002), is expressed in planarian neoblasts and brain neurons (Salvetti et al. 2005). RNAi-mediated knock-down of Djpum leads to loss of regeneration and a reduction of neoblast number in D. japonica (Salvetti et al. 2005). Notably, DjCBC-1 homologue Dhh1p interacts physically with Pumilio homologue Mpt5p in yeast extracts (Goldstrohm et al. 2006), which implies that DjPum may also be associated with chromatoid bodies. Similar results with regard to phenotype and expression pattern were observed for bruli in $S$. mediterranea (Guo et al. 2006). Smed-bruli is a member of the Bruno-like family of proteins, which includes bruno, an RNA-binding protein that represses translation of osk mRNA in Drosophila germline cells (Webster et al. 1997; Nakamura et al. 2004).

\section{Other RNP component homologue genes in the neoblasts}

Genes shown to be components of dense ribonucleoprotein structures such as mammalian chromatoid bodies, stress granules and processing bodies (P bodies) are expressed in the neoblasts. These ribonucleoprotein 


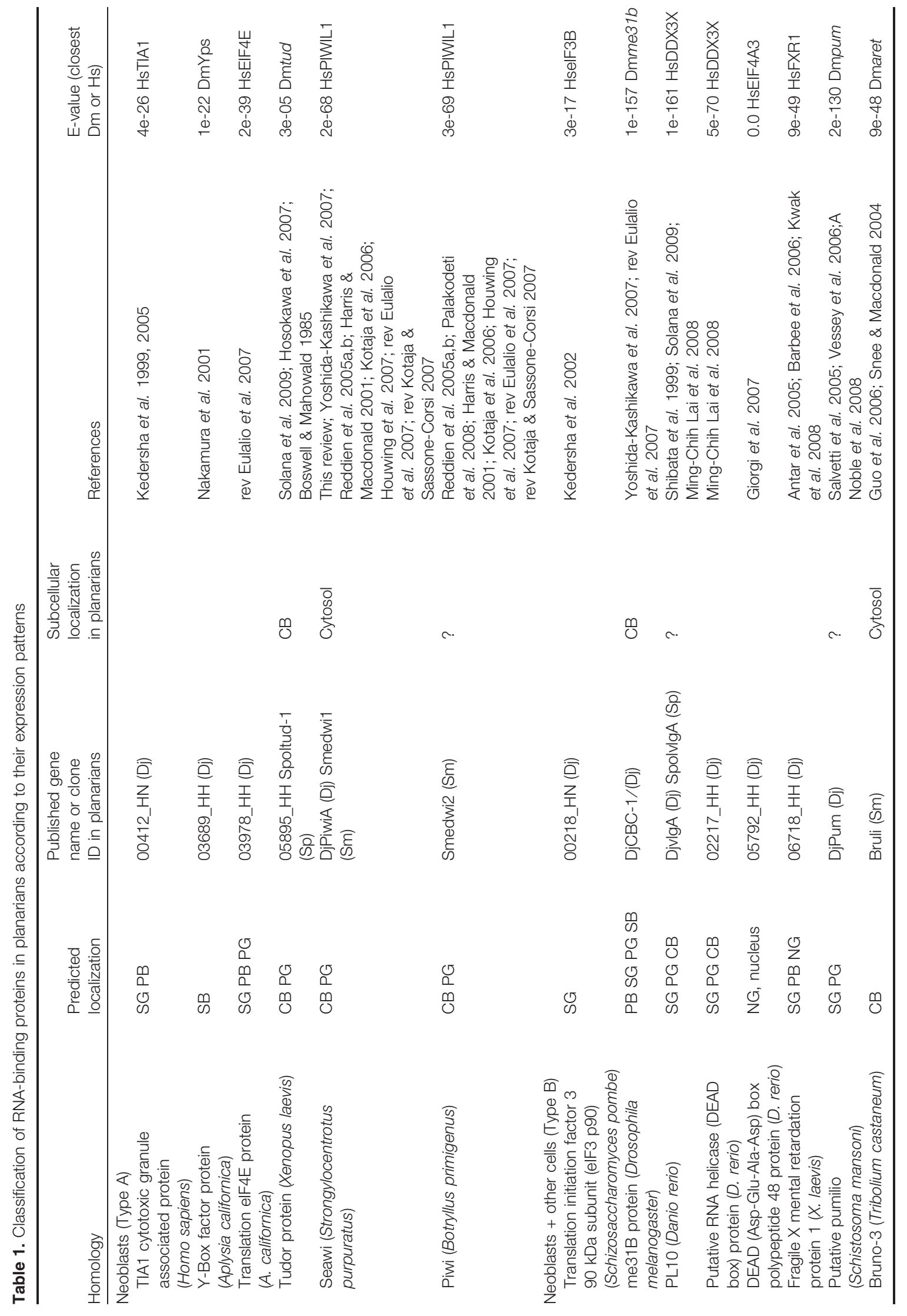


complexes are implicated in different modes of posttranscriptional regulation of gene expression, such as mRNA decay, mRNA storage and translational repression (Eulalio et al. 2007; Besse \& Ephrussi 2008; Balagopal \& Parker 2009). In order to consider the composition and function of chromatoid bodies in planarians, we have categorized genes encoding planarian RNA-binding proteins into Type A, Type B, or subpopulation of neoblasts (Table 1). Type A means neoblast-specific genes (Fig. 5A). Among proteins encoded by Type A genes, TIA is a stress granule and $\mathrm{P}$ body component involved in translational repression and stress granule formation (Forch et al. 2000; Kedersha et al. 2000; Dixon et al. 2003). This gene is also known to regulate alternative splicing of apoptosis-promoting factor Fas mRNA (Izquierdo et al. 2005). Interestingly, neoblast death seems to occur in an apoptotic manner not only under stress conditions, such as irradiation or depletion of vital factors, but also in intact planarians (Hwang et al. 2004; Salvetti et al. 2005). The TIA expression in the neoblasts suggests that stress granules could exist in neoblasts under stress conditions. Type B genes, some of which are required for neoblast maintenance, are expressed in both the stem cells and brain neurons (Fig. 5B; Salvetti et al. 2005; Guo et al. 2006; Yoshida-Kashikawa et al. 2007), indicating that those two types of cells have similar post-transcriptional regulation mechanisms. Interestingly, not all chromatoid bodies contain DjCBC1 (categorized as Type B) (Fig. 5B and Table 1 Yoshida-Kashikawa et al. 2007), which suggests heterogeneity of chromatoid bodies. One possible reason for this heterogeneity may be an association of the chromatoid bodies with other kinds of RNP granules.

\section{miRNA in the neoblasts}

Another class of small non-coding RNA that is robustly expressed in planarians is microRNAs (miRNAs), which are message-specific regulators of gene expression (Palakodeti et al. 2006; Friedländer et al. 2009; González-Estévez et al. 2009; Lu et al. 2009). Large-scale profiling by two different laboratories identified 10 S. mediterranea miRNAs whose expression was enriched in neoblasts, five of which were classified as enriched by both groups (Friedländer et al. 2009; Lu et al. 2009). Interestingly, the function of chromatoid body components during mouse spermiogenesis can be divided into repression of retrotransposons or miRNA processing, by the fact that Miwi and Mili are necessary for retrotransposon silencing, whereas Tudor domain protein Tdrd6 is required for proper expression of miRNAs (Vasileva et al. 2009; Wang et al. 2009). Something similar could be occurring in 
the chromatoid bodies of planarian neoblasts, although DjPiwiA is not localized in the chromatoid bodies.

\section{Germline cell specification from neoblasts by nanos}

Chromatoid bodies are also detected in planarian germline cells (Teshirogi \& Ishida 1987). Sexual-state planarians develop mature testes located dorsolaterally, and a pair of ovaries in the ventral side of the neck region, both of which are completely absent in asexual planarians (Newmark et al. 2008). The expression of some neoblast components has been confirmed in germline cells of sexual planarians (Shibata et al. 1999; Newmark et al. 2008; Solana et al. 2009), suggesting a parallel program for regulation of gene expression among neoblast and germline cells in planarians as well.

What regulates the emergence of the mature germline? Which genes are responsible for germline cell specification? These questions were partially answered with the identification of nanos, a $\mathrm{CCHC}$ zinc-finger protein, which plays a crucial role in germline cell establishment in early embryogenesis, and in germline stem cell maintenance and differentiation, by inhibiting translation of specific mRNAs (Forbes \& Lehmann 1998; Asaoka-Taguchi et al. 1999; Kraemer et al. 1999; Wang \& Lin 2004; Kobayashi 2005; Nakamura \& Seydoux 2008). In planarians, nanos (or nos) is specifically expressed in sparmatogonia and oogonia of sexual planarians, as well as in germline precursor cells in asexual animals (Fig. 5C; Sato et al. 2006; Wang et al. 2007). Depletion of nanos by RNAi in S. mediterranea causes clear loss of testis, ovaries and germ cell precursors, but not neoblasts. The co-expression of several neoblast marker genes and nanos in asexual planarians indicates that nanos-expressing cells are a subpopulation of neoblasts (Table 1; Wang et al. 2007). These cells differentiate into mature gonads during epigenetic sexual specification in planarians, suggesting that nanos-positive cells in asexual individuals are germline precursor cells (Sato et al. 2006). Neoblasts show constant cell division, even in intact animals (Newmark \& Sánchez Alvarado 2000; Kang \& Sánchez Alvarado 2009), whereas germline precursors seem to be arrested at the G2 phase, analogous to Nos-regulated presumptive germline precursor cells (PGCs) in Drosophila (Asaoka-Taguchi et al. 1999; Sato et al. 2006).

\section{Conclusions regarding "molecular features of the neoblasts"}

A pattern is emerging, in which homologues of posttranscriptional regulators in the germline and early development of other organisms (Wickens et al. 2000; Seydoux \& Braun 2006) are expressed in the neoblast and/or required to maintain the stemness and viability of neoblasts. Thus, neoblast chromatoid bodies are likely to be involved in post-transcriptional regulation of mRNA, although further studies will be needed to determine their function in detail (Fig. 6A). The mentioned reports indicate that molecular mechanisms common to planarian pluripotent somatic stem cells and germline cells are required for neoblast maintenance: strong post-transcriptional regulation by several RNA-binding proteins and miRNAs, and the assurance of genomic stability required for pluripotency or totipotency by inactivation of transposable elements by Piwi and piRNAs (Fig. 6A).

Generally, the most fundamental difference between somatic and germline stem cells is the inability of

\section{(A) Neoblast}

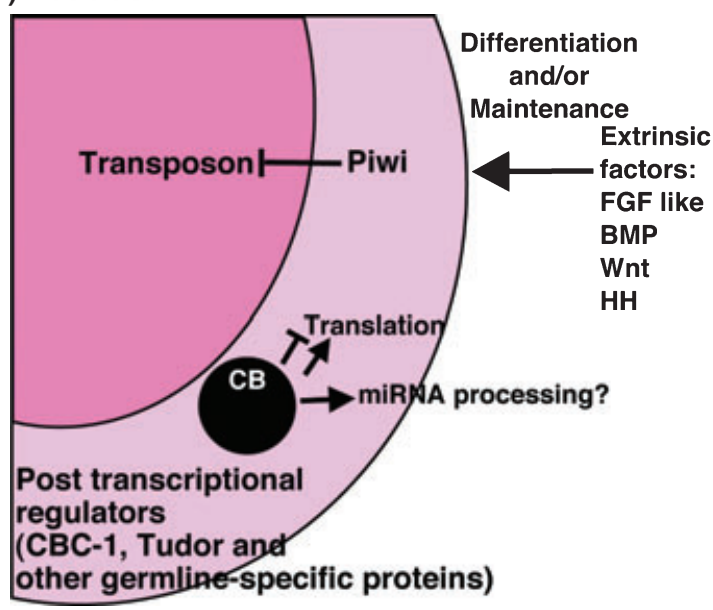

\section{(B) Germline precursor}

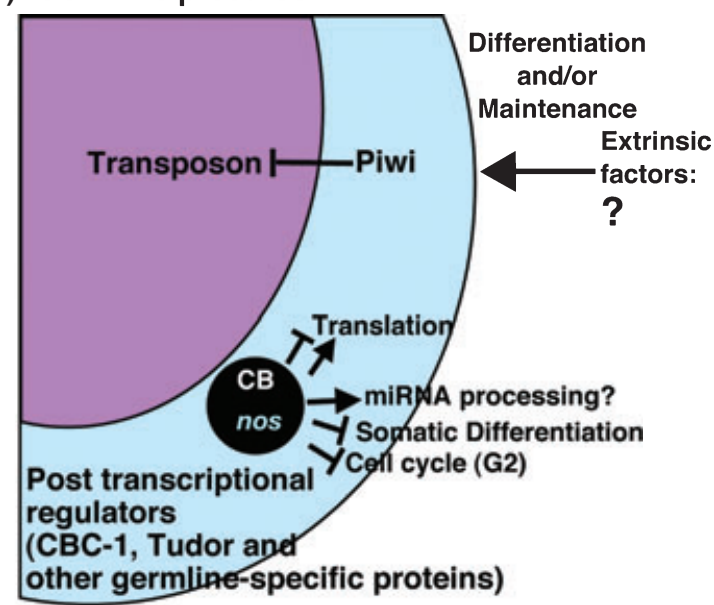

Fig. 6. Model of molecular mechanisms that regulate (A) neoblasts and (B) germline precursor cells. 
germline stem cells to differentiate into somatic cells, in order to assure progeny via sexual reproduction. In Drosophila, nanos-deficient PGCs adopt both somatic and germline fate (Hayashi et al. 2004), which indicates that nanos is crucial for preventing the adoption of somatic fate by germline precursors, and that PGCs have innate multipotency. Based on this, neoblasts maintain pluripotency and therefore can give rise to all types of cells for both asexual and sexual reproduction. Thus, neoblasts possess molecular mechanisms akin to those in germline cells, but germline precursors must maintain their germline-restricted fate until sexualization (Fig. 6B). It is likely that nanos is involved in inhibition of the cell cycle, apoptosis, and differentiation into the somatic state in asexual planarians as well as Drosophila PGCs (Hayashi et al. 2004; Sato et al. 2007). The molecular mechanisms for specification of germline precursors in planarians, apart from the involvement of nanos, are still unclear. Comprehensive gene analysis of germline-specific genes, however, will probably identify genes that play a role upstream, downstream, or with nanos (Zayas et al. 2005; Newmark et al. 2008). Better understanding of the process of epigenetic germline specification in planarians should shed light on vertebrate gametogenesis and the evolution of germline cells (Extavour 2007). Thus, planarian stem cells will also provide a good opportunity to understand not only evolutionary aspects of pluripotent stem cells and germline cells, but also the RNA world in the stem cells.

\section{Signaling molecules involved in neoblast regulation}

Recently, it has been shown that differentiation of the neoblasts seems likely to be regulated by several signaling molecules. RNAi-silencing of $\beta$-catenin, which is known to be involved in wnt signaling in other animals, in S. mediterranea leads to ectopic head formation in the tail region (Gurley et al. 2008; Petersen \& Reddien 2008; Adell et al. 2009). Bone morphogenetic protein (BMP) is also required for proper regeneration and maintenance of the dorsoventral axis in planarians (Molina et al. 2007; Orii \& Watanabe 2007; Reddien et al. 2007). nou-darake (ndk) encodes a fibroblast growth factor receptor (FGFR) like protein, which lacks an intracellular domain (Cebria et al. 2002a). After knockdown of ndk, ectopic brains are formed beyond the head region (Cebria et al. 2002a). Triple knockdown of ndk and two FGF receptors expressed in the neoblasts of D. japonica, DjFGFR1 and DJFGFR2, (Ogawa et al. 2002) inhibits ectopic brain formation, suggesting that FGF-like signaling is involved in brain cell differentiation (Cebria et al. 2002a; Umesono \&
Agata 2009). Also, hedgehog (Shh) signaling controls A-P patterning (Yazawa et al. in press). All of these facts suggest that several signaling molecules direct the proper differentiation of the neoblasts (Fig. 5A). Interestingly, signaling molecules involved in these pathways are also involved in the regulation of ASCs or germline stem cells in other model organisms. Bone morphogenetic protein (BMP) and Shh are required for germline stem cell maintenance and differentiation in flies. Wnt signaling is required for hair follicle stem cell differentiation in mammals, and FGF for differentiation of embryonic stem (ES) cells (Wong et al. 2005; Kunath et al. 2007; Nishikawa \& Osawa 2007; Ying et al. 2008). These connections indicate that the molecular basis for the regulation of pluripotency or multipotency is probably conserved in species among various phyla.

\section{Conclusions and future prospects}

The expression of genes that are exclusive to the germline in vertebrates is also observed in pluripotent or multipotent ASCs in basal metazoans and some bilaterians, archeocytes of Porifera, interstitial cells of Cnidaria, neoblasts of Annelida, and stem cells of parasitic Arthropoda (Mochizuki et al. 2000, 2001; Shukalyuk et al. 2007; Sugio et al. 2008; Funayama et al. unpubl. data, 2010). As is the case with planarians, these organisms perform asexual reproduction using pluripotent or mulitipotent ASCs, which suggests that the use of "germline-specific genes" by somatic stem cells may be a way to achieve asexual reproduction (Agata et al. 2006). Furthermore, these basal metazoans produce germline cells from ASCs, which implies that ASCs might have been the evolutionary origin of germline cells (Extavour 2007). Colonial ascidians belonging to Urochordata can also reproduce asexually; however, their multipotent ASCs don't seem to express "germline-specific genes" (Sunanaga et al. 2006, 2007, 2008). One explanation for this could be the suggested separation of somatic and germline stem cells in colonial ascidians (Laird et al. 2005). Thus, basic research about ASCs in diverse species of various phyla provides a great opportunity to get insight into cell contributions to reproduction, as well as the origin and evolution of germline cells. Comparison of molecular signatures of ASCs in these animals and ASCs in relatively higher metazoans, such as vertebrates, will reveal the common molecular bases of stem cells.

In addition to the natural advantages of planarians, recent technical and bioinformatics advances in planarian stem cell research have made planarians the model organism of choice for studies of stem cell 
biology in vivo (Sánchez Alvarado \& Kang 2005; Rossi et al. 2008) and epigenetic specification of germ cells (Newmark et al. 2008). As reviewed here, planarians are also intriguing animals for research on RNA regulation and cytoplasmic ribonucleoprotein structures.

Many fundamental issues remain to be resolved. In 1990, Professor K. Watanabe established clonal strains, gifu iruma (Gl) and sexualizing special planarian (SSP), from single $D$. japonica individuals. For approximately 20 years, both strains have been asexually maintained in the laboratory. However, we still don't know how neoblasts maintain pluripotency and genomic stability over time despite their continuous and rapid division (Kang \& Sánchez Alvarado 2009). How planarians maintain a constant number of the neoblasts $(\sim 30 \%)$ in their body is also unclear. Whether there is a stem cell "niche", which is known to be an important place or group of cells for the regulation of stem cells in other animals, is not known in planarians. We tried to identify neuronal stem cells in planarians by analysis of musashi homologues, but there was no clear evidence of their existence (Higuchi et al. 2008). In fact, whether there are any lineage-committed adult stem cells in planarians, apart from germline precursors, is still unclear. Understanding the complexity and biological-state flexibility of neoblasts in planarians will advance our knowledge of stem cells in general, and the application of ES or iPS cells in the medical field.

\section{Acknowledgments}

We appreciate all of our colleagues engaged in stem cell research. We also thank E. Nakajima for critical reading of the manuscript. This review was written partially based on studies supported by a Grant-in-Aid for Creative Scientific Research to K. A. (17GS0318), the Global COE program A06 of Kyoto University, and the Naito Foundation. L.R. is supported by a National Science Foundation Minority Postdoctoral Research Fellowship (Award \#0 804 021).

\section{References}

Adell, T., Salò, E., Boutros, M. \& Bartscherer, K. 2009. Smed-Evi/Wntless is required for beta-catenin-dependent and -independent processes during planarian regeneration. Development 136, 905-910.

Agata, K., Nakajima, E., Funayama, N., Shibata, N., Saito, Y. \& Umesono, Y. 2006. Two different evolutionary origins of stem cell systems and their molecular basis. Semin. Cell Dev. Biol. 17, 503-509.

Agata, K., Soejima, Y., Kato, K., Kobayashi, C., Umesono, Y. \& Watanabe, K. 1998. Structure of the planarian central nervous system (CNS) revealed by neuronal cell markers. Zool. Sci. 15, 433-440.
Agata, K., Tanaka, T., Kobayashi, C., Kato, K. \& Saitoh, Y. 2003. Intercalary regeneration in planarians. Dev. Dyn. 226, 308316.

Agata, K. \& Watanabe, K. 1999. Molecular and cellular aspects of planarian regeneration. Semin. Cell Dev. Biol. 10, 377383.

Antar, L. N., Dictenberg, J. B., Plociniak, M., Afroz, R. \& Bassell, G. J. 2005. Localization of FMRP-associated mRNA granules and requirement of microtubules for activity-dependent trafficking in hippocampal neurons. Genes Brain Behav. 4, 350-359.

Aravin, A. A., Sachidanandam, R., Girard, A., Fejes-Toth, K. \& Hannon, G. J. 2007. Developmentally regulated piRNA clusters implicate MILI in transposon control. Science 316, 744747.

Asaoka-Taguchi, M., Yamada, M., Nakamura, A., Hanyu, K. \& Kobayashi, S. 1999. Maternal Pumilio acts together with Nanos in germline development in Drosophila embryos. Nat. Cell Biol. 1, 431-437.

Auladell, C., Garcia-Valero, J. \& Baguñà, J. 1993. Ultrastructural localization of RNA in the chromatoid bodies of undifferentiated cells (neoblasts) in planarians by the RNase-gold complex technique. J. Morphol. 216, 319-326.

Baguñà, J. 1974. Dramatic mitotic response in planarians after feeding, and a hypothesis for the control mechanism. J. Exp. Zool. 190, 117-122.

Baguñà, J. 1975. Mitosis in the intact and regenerating planarian Dugesia mediterranea n.sp. I. Mitotic studies during growth, feeding and starvation. J. Exp. Zool. 195, 53-64.

Baguñà, J. 1981. Planarian neoblasts. Nature 290, 14-15.

Baguñà, J., Salò, E. \& Auladell, C. 1989. Regeneration and pattern formation in planarians. III. Evidence that neoblasts are totipotent stem cells and the source of blastema cells. Development 107, 77-86.

Balagopal, V. \& Parker, R. 2009. Polysomes, P bodies and stress granules: states and fates of eukaryotic mRNAs. Curr. Opin. Cell Biol. 21, 403-408.

Barbee, S. A., Estes, P. S., Cziko, A. M., Hillebrand, J., Luedeman, R. A., Coller, J. M., Johnson, N., Howlett, I. C., Geng, C., Ueda, R., Brand, A. H., Newbury, S. F., Wilhelm, J. E., Levine, R. B., Nakamura, A., Parker, R. \& Ramaswami, M. 2006. Staufen- and FMRP-containing neuronal RNPs are structurally and functionally related to somatic $\mathrm{P}$ bodies. Neuron 52, 997-1009.

Besse, F. \& Ephrussi, A. 2008. Translational control of localized mRNAs: restricting protein synthesis in space and time. Nat. Rev. Mol. Cell Biol. 9, 971-980.

Bosch, T. C. G. 2008. Stem Cells From Hydra to Man. SpringerVerlag, New York.

Boswell, R. E. \& Mahowald, A. P. 1985. tudor, a gene required for assembly of the germ plasm in Drosophila melanogaster. Cell 43, 97-104.

Carmell, M. A., Girard, A., Van De Kant, H. J., Bourc'his, D., Bestor, T. H., De Rooij, D. G. \& Hannon, G. J. 2007. MIWI2 is essential for spermatogenesis and repression of transposons in the mouse male germline. Dev. Cell 12, 503-514.

Cebria, F., Kobayashi, C., Umesono, Y., Nakazawa, M., Mineta, K., Ikeo, K., Gojobori, T., Itoh, M., Taira, M., Sánchez Alvarado, A. \& Agata, K. 2002a. FGFR-related gene noudarake restricts brain tissues to the head region of planarians. Nature 419, 620-624.

Cebria, F., Kudome, T., Nakazawa, M., Mineta, K., Ikeo, K., Gojobori, T. \& Agata, K. 2002b. The expression of neuralspecific genes reveals the structural and molecular complexity 
of the planarian central nervous system. Mech. Dev. 116, 199-204.

Cebria, F., Nakazawa, M., Mineta, K., Ikeo, K., Gojobori, T. \& Agata, K. 2002c. Dissecting planarian central nervous system regeneration by the expression of neural-specific genes. Dev. Growth Differ. 44, 135-146.

Coward, S. J. 1974. Chromatoid bodies in somatic cells of the planarian: observations on their behavior during mitosis. Anat. Rec. 180, 533-545.

Cox, D. N., Chao, A., Baker, J., Chang, L., Qiao, D. \& Lin, H. 1998. A novel class of evolutionarily conserved genes defined by piwi are essential for stem cell self-renewal. Genes Dev. 12, 3715-3727.

Crittenden, S. L., Bernstein, D. S., Bachorik, J. L., Thompson, B. E., Gallegos, M., Petcherski, A. G., Moulder, G., Barstead, R., Wickens, M. \& Kimble, J. 2002. A conserved RNA-binding protein controls germline stem cells in Caenorhabditis elegans. Nature 417, 660-663.

Dixon, D. A., Balch, G. C., Kedersha, N., Anderson, P., Zimmerman, G. A., Beauchamp, R. D. \& Prescott, S. M. 2003 Regulation of cyclooxygenase-2 expression by the translational silencer TIA-1. J. Exp. Med. 198, 475-481.

Eisenhoffer, G. T., Kang, H. \& Sánchez Alvarado, A. 2008. Molecular analysis of stem cells and their descendants during cell turnover and regeneration in the planarian Schmidtea mediterranea. Cell Stem Cell 3, 327-339.

Eulalio, A., Behm-Ansmant, I. \& Izaurralde, E. 2007. P bodies: at the crossroads of post-transcriptional pathways. Nat. Rev. Mol. Cell Biol. 8, 9-22.

Extavour, C. G. M. 2007. Evolution of the bilaterian germ line: lineage origin and modulation of specification mechanisms. Integr. Comp. Biol. 47, 770-785.

Forbes, A. \& Lehmann, R. 1998. Nanos and Pumilio have critical roles in the development and function of Drosophila germline stem cells. Development 125, 679-690.

Forch, P., Puig, O., Kedersha, N., Martinez, C., Granneman, S., Seraphin, B., Anderson, P. \& Valcarcel, J. 2000. The apoptosis-promoting factor TIA-1 is a regulator of alternative pre-mRNA splicing. Mol. Cell 6, 1089-1098.

Friedländer, M. R., Adamidi, C., Han, T., Lebedeva, S., Isenbarger, T. A., Hirst, M., Marra, M., Nusbaum, C., Lee, W. L. Jenkin, J. C., Sánchez Alvarado, A., Kim, J. K. \& Rajewsky, N. 2009. High-resolution profiling and discovery of planarian small RNAs. Proc. Natl Acad. Sci. USA 14, 11546-11551.

Fuchs, E. 2009. The tortoise and the hair: slow-cycling cells in the stem cell race. Cell 137, 811-819.

Fujiwara, Y., Komiya, T., Kawabata, H., Sato, M., Fujimoto, H. Furusawa, M. \& Noce, T. 1994. Isolation of a DEAD-family protein gene that encodes a murine homolog of Drosophila vasa and its specific expression in germ cell lineage. Proc. Natl Acad. Sci. USA 91, 12258-12262.

Giorgi, C., Yeo, G. W., Stone, M. E., Katz, D. B., Burge, C., Turrigiano, G. \& Moore, M. J. 2007. The EJC factor elF4All modulates synaptic strength and neuronal protein expression. Cell 130, 179-191.

Girard, A. \& Hannon, G. J. 2007. The role of piRNAs in mouse spermatogenesis. J. Soc. Biol. 201, 411-418.

Goldstrohm, A. C., Hook, B. A., Seay, D. J. \& Wickens, M. 2006. PUF proteins bind Pop2p to regulate messenger RNAs. Nat. Struct. Mol. Biol. 13, 533-539.

González-Estévez, C., Arseni, V., Thambyrajah, R. S., Felix, D. A. \& Aboobaker, A. A. 2009. Diverse miRNA spatial expression patterns suggest important roles in homeostasis and regeneration in planarians. Int. J. Dev. Biol. 53, 493-505.
Guo, T., Peters, A. H. \& Newmark, P. A. 2006. A bruno-like gene is required for stem cell maintenance in planarians. Dev. Cell 11, 159-169.

Gurley, K. A., Rink, J. C. \& Sánchez Alvarado, A. 2008. Betacatenin defines head versus tail identity during planarian regeneration and homeostasis. Science 319, 323-327.

Gurley, K. A. \& Sánchez Alvarado, A. 2008. Stem cells in animal models of regeneration. In: The Stem Cell Research Community, (ed. StemBook). StemBook. doi/10.3824/stembook.1.32.1, http://www.stembook.org.

Handberg-Thorsager, M. \& Salò, E. 2007. The planarian nanoslike gene Smednos is expressed in germline and eye precursor cells during development and regeneration. Dev. Genes. Evol. 217, 403-411.

Harris, A. N. \& Macdonald, P. M. 2001. Aubergine encodes a Drosophila polar granule component required for pole cell formation and related to elF2C. Development 128, 28232832.

Hayashi, T., Asami, M., Higuchi, S., Shibata, N. \& Agata, K. 2006. Isolation of planarian X-ray-sensitive stem cells by fluorescence-activated cell sorting. Dev. Growth Differ. 48 , 371-380.

Hayashi, Y., Hayashi, M. \& Kobayashi, S. 2004. Nanos suppresses somatic cell fate in Drosophila germ line. Proc. Natl Acad. Sci. USA 101, 10338-10342.

Higuchi, S., Hayashi, T., Hori, I., Shibata, N., Sakamoto, H. \& Agata, K. 2007. Characterization and categorization of fluorescence activated cell sorted planarian stem cells by ultrastructural analysis. Dev. Growth Differ. 49, 571-581.

Higuchi, S., Hayashi, T., Tarui, H., Nishimura, O., Nishimura, K., Shibata, N., Sakamoto, H. \& Agata, K. 2008. Expression and functional analysis of musashi-like genes in planarian CNS regeneration. Mech. Dev. 125, 631-645.

Hori, I. 1982. An ultrastructural study of the chromatoid body in planarian regenerative cells. J. Electron Microsc. 31, 63-72.

Hori, I. 1992. Cytological approach to morphogenesis in the planarian blastema. I. Cell behavior during blastema formation. J. Submicrosc. Cytol. Pathol. 24, 75-84.

Hori, I. 1997. Cytological approach to morphogenesis in the planarian blastema. II. The effect of neuropeptides. J. Submicrosc. Cytol. Pathol. 29, 91-97.

Hosokawa, M., Shoji, M., Kitamura, K., Tanaka, T., Noce, T., Chuma, S. \& Nakatsuji, N. 2007. Tudor-related proteins TDRD1/MTR-1, TDRD6 and TDRD7/TRAP: domain composition, intracellular localization, and function in male germ cells in mice. Dev. Biol. 301, 38-52.

Houwing, S., Kamminga, L. M., Berezikov, E., Cronembold, D., Girard, A., Van Den Elst, H., Filippov, D. V., Blaser, H., Raz, E., Moens, C. B., Plasterk, R. H., Hannon, G. J., Draper, B. W. \& Ketting, R. F. 2007. A role for Piwi and piRNAs in germ cell maintenance and transposon silencing in Zebrafish. Cell 129, 69-82.

Hwang, J. S., Kobayashi, C., Agata, K., Ikeo, K. \& Gojobori, T. 2004. Detection of apoptosis during planarian regeneration by the expression of apoptosis-related genes and TUNEL assay. Gene $\mathbf{3 3 3}, \mathbf{1 5}-25$

Inoue, T., Hayashi, T., Takechi, K. \& Agata, K. 2007. Clathrinmediated endocytic signals are required for the regeneration of, as well as homeostasis in, the planarian CNS. Development 134, 1679-1689.

Izquierdo, J. M., Majos, N., Bonnal, S., Martinez, C., Castelo, R., Guigo, R., Bilbao, D. \& Valcarcel, J. 2005. Regulation of Fas alternative splicing by antagonistic effects of TIA-1 and PTB on exon definition. Mol. Cell 19, 475-484. 
Jaruzelska, J., Kotecki, M., Kusz, K., Spik, A., Firpo, M. \& Reijo Pera, RA. 2003. Conservation of a Pumilio-Nanos complex from Drosophila germ plasm to human germ cells. Dev. Genes Evol.. 213, 120-126.

Kang, H. \& Sánchez Alvarado, A. 2009. Flow cytometry methods for the study of cell-cycle parameters of planarian stem cells. Dev. Dyn. 238, 1111-1117.

Kato, K., Orii, H., Watanabe, K. \& Agata, K. 1999. The role of dorsoventral interaction in the onset of planarian regeneration. Development 126, 1031-1040.

Kato, K., Orii, H., Watanabe, K. \& Agata, K. 2001. Dorsal and ventral positional cues required for the onset of planarian regeneration may reside in differentiated cells. Dev. Biol. 233, 109-121.

Kedersha, N., Chen, S., Gilks, N., Li, W., Miller, I. J., Stahl, J. \& Anderson, P. 2002. Evidence that ternary complex (elF2GTP-tRNA(i)(Met))-deficient preinitiation complexes are core constituents of mammalian stress granules. Mol. Biol. Cell 13, 195-210.

Kedersha, N., Cho, M. R., Li, W., Yacono, P. W., Chen, S., Gilks, N., Golan, D. E. \& Anderson, P. 2000. Dynamic shuttling of TIA-1 accompanies the recruitment of mRNA to mammalian stress granules. J. Cell Biol. 151, 1257-1268.

Kedersha, N., Stoecklin, G., Ayodele, M., Yacono, P., LykkeAndersen, J., Fritzler, M. J., Scheuner, D., Kaufman, R. J., Golan, D. E. \& Anderson, P. 2005. Stress granules and processing bodies are dynamically linked sites of mRNP remodeling. J. Cell Biol. 169, 871-884.

Kedersha, N. L., Gupta, M., Li, W., Miller, I. \& Anderson, P. 1999. RNA-binding proteins TIA-1 and TIAR link the phosphorylation of elF-2 alpha to the assembly of mammalian stress granules. J. Cell Biol. 147, 1431-1442.

Kobayashi, C., Kobayashi, S., Orii, H., Watanabe, K. \& Agata, K. 1998. Identification of two distinct muscles in the planarian Dugesia japonica by their expression of myosin heavy chain genes. Zool. Sci. 15, 855-863.

Kobayashi, C., Nogi, T., Watanabe, K. \& Agata, K. 1999. Ectopic pharynx arise by regional reorganization after anterior/posterior chimera in planarians. Mech. Dev. 89, 25-34.

Kobayashi, K., Hashiguchi, T., Ichikawa, T., Ishino, Y., Hoshi, M. \& Matsumoto, M. 2008. Neoblast-enriched fraction rescues eye formation in eye-defective planarian 'menashi' Dugesia ryukyuensis. Dev. Growth Differ. 50, 689-696.

Kobayashi, S. 2005. The mechanisms underlying germline development in Drosophila embryos. Zool. Sci. 22, 1367-1369.

Kotaja, N., Lin, H., Parvinen, M. \& Sassone-Corsi, P. 2006. Interplay of PIWI/Argonaute protein MIWI and kinesin KIF17b in chromatoid bodies of male germ cells. J. Cell Sci. 119, 2819-2825.

Kotaja, N. \& Sassone-Corsi, P. 2007. The chromatoid body: a germ-cell-specific RNA-processing centre. Nat. Rev. Mol. Cell Biol. 8, 85-90.

Kraemer, B., Crittenden, S., Gallegos, M., Moulder, G., Barstead, R., Kimble, J. \& Wickens, M. 1999. NANOS-3 and FBF proteins physically interact to control the sperm-oocyte switch in Caenorhabditis elegans. Curr. Biol. 9, 1009-1018.

Kunath, T., Saba-El-Leil, M. K., Almousailleakh, M., Wray, J., Meloche, S. \& Smith, A. 2007. FGF stimulation of the Erk1/2 signalling cascade triggers transition of pluripotent embryonic stem cells from self-renewal to lineage commitment. Development 134, 2895-2902.

Kuramochi-Miyagawa, S., Kimura, T., ljiri, T. W., Isobe, T., Asada, N., Fujita, Y., Ikawa, M., Iwai, N., Okabe, M., Deng, W., Lin, H., Matsuda, Y. \& Nakano, T. 2004. Mili, a mammalian member of piwi family gene, is essential for spermatogenesis. Development 131, 839-849.

Kwak, J. E., Drier, E., Barbee, S. A., Ramaswami, M., Yin, J. C. \& Wickens, M. 2008. GLD2 poly(A) polymerase is required for long-term memory. Proc. Natl Acad. Sci. USA 105, 14644-14649.

Lai, M. C., Lee, Y. H. \& Tarn, W. Y. 2008. The DEAD-box RNA helicase DDX3 associates with export messenger ribonucleoproteins as well as tip-associated protein and participates in translational control. Mol. Biol. Cell 19, 3847-3858.

Laird, D. J., De Tomaso, A. W. \& Weissman, I. L. 2005. Stem cells are units of natural selection in a colonial ascidian. Cell 123, 1351-1360.

Lasko, P. F. \& Ashburner, M. 1988. The product of the Drosophila gene vasa is very similar to eukaryotic initiation factor-4A. Nature 335, 611-617.

Lin, H. \& Spradling, A. C. 1997. A novel group of pumilio mutations affects the asymmetric division of germline stem cells in the Drosophila ovary. Development 124, 2463-2476.

Lu, Y. C., Smielewska, M., Palakodeti, D., Lovci, M. T., Aigner, S., Yeo, G. W. \& Graveley, B. R. 2009. Deep sequencing identifies new and regulated microRNAs in Schmidtea mediterranea. RNA 15, 1483-1491.

Malone, C. D. \& Hannon, G. J. 2009. Small RNAs as guardians of the genome. Cell 136, 656-668.

Mochizuki, K., Nishimiya-Fujisawa, C. \& Fujisawa, T. 2001. Universal occurrence of the vasa-related genes among metazoans and their germline expression in Hydra. Dev. Genes. Evol. 211, 299-308.

Mochizuki, K., Sano, H., Kobayashi, S., Nishimiya-Fujisawa, C. \& Fujisawa, T. 2000. Expression and evolutionary conservation of nanos-related genes in Hydra. Dev. Genes. Evol. 210, 591-602.

Molina, M. D., Salò, E. \& Cebria, F. 2007. The BMP pathway is essential for re-specification and maintenance of the dorsoventral axis in regenerating and intact planarians. Dev. Biol. 311, 79-94.

Morgan, T. M. 1898. Experimental studies of the regeneration of Planaria maculata. Archiv $f$. Entwicklungsgesch VII, 364-97.

Morita, M. 1967. Observations on the fine structure of the neoblast and its cell division in the regenerating planaria. Sci. Rep. Tohoku Univ. 33, 399-406.

Nakamura, A., Amikura, R., Hanyu, K. \& Kobayashi, S. 2001. Me31B silences translation of oocyte-localizing RNAs through the formation of cytoplasmic RNP complex during Drosophila oogenesis. Development 128, 3233-3242.

Nakamura, A., Sato, K. \& Hanyu-Nakamura, K. 2004. Drosophila cup is an elF4E binding protein that associates with Bruno and regulates oskar mRNA translation in oogenesis. Dev. Cell 6, 69-78.

Nakamura, A. \& Seydoux, G. 2008. Less is more: specification of the germline by transcriptional repression. Development $\mathbf{1 3 5}$, 3817-3827.

Newmark, P. A. \& Sánchez Alvarado, A. 2000. Bromodeoxyuridine specifically labels the regenerative stem cells of planarians. Dev. Biol. 220, 142-153.

Newmark, P. A. \& Sánchez Alvarado, A. 2002. Not your father's planarian: a classic model enters the era of functional genomics. Nat. Rev. Genet. 3, 210-219.

Newmark, P. A., Wang, Y. \& Chong, T. 2008. Germ cell specification and regeneration in planarians. Cold Spring Harb. Symp. Quant. Biol. 73, 295-370.

Nishikawa, S. \& Osawa, M. 2007. Generating quiescent stem cells. Pigment Cell Res. 20, 263-270. 
Nishimura, K., Kitamura, Y., Inoue, T., Umesono, Y., Sano, S., Yoshimoto, K., Inden, M., Takata, K., Taniguchi, T., Shimohama, S. \& Agata, K. 2007a. Reconstruction of dopaminergic neural network and locomotion function in planarian regenerates. Dev. Neurobiol. 67, 1059-1078.

Nishimura, K., Kitamura, Y., Inoue, T., Umesono, Y., Yoshimoto, K., Takeuchi, K., Taniguchi, T. \& Agata, K. 2007b. Identification and distribution of tryptophan hydroxylase (TPH)-positive neurons in the planarian Dugesia japonica. Neurosci. Res. 59, 101-106.

Noble, S. L., Allen, B. L., Goh, L. K., Nordick, K. \& Evans, T. C. 2008. Maternal mRNAs are regulated by diverse $P$ bodyrelated mRNP granules during early Caenorhabditis elegans development. J. Cell Biol. 182, 559-572.

Ogawa, K., Kobayashi, C., Hayashi, T., Orii, H., Watanabe, K. \& Agata, K. 2002. Planarian fibroblast growth factor receptor homologs expressed in stem cells and cephalic ganglions. Dev. Growth Differ. 44, 191-204.

Orii, H., Sakurai, T. \& Watanabe, K. 2005. Distribution of the stem cells (neoblasts) in the planarian Dugesia japonica. Dev. Genes. Evol. 215, 143-157.

Orii, H. \& Watanabe, K. 2007. Bone morphogenetic protein is required for dorso-ventral patterning in the planarian Dugesia japonica. Dev. Growth Differ. 49, 345-349.

Oviedo, N. J. \& Levin, M. 2007. smedinx-11 is a planarian stem cell gap junction gene required for regeneration and homeostasis. Development 134, 3121-3131.

Palakodeti, D., Smielewska, M. \& Graveley, B. R. 2006. MicroRNAs from the Planarian Schmidtea mediterranea: a model system for stem cell biology. RNA 12, 1640-1649.

Palakodeti, D., Smielewska, M., Lu, Y. C., Yeo, G. W. \& Graveley, B. R. 2008. The PIWI proteins SMEDWI-2 and SMEDWI-3 are required for stem cell function and piRNA expression in planarians. RNA 14, 1174-1186.

Parisi, M. \& Lin, H. 1999. The Drosophila pumilio gene encodes two functional protein isoforms that play multiple roles in germline development, gonadogenesis, oogenesis and embryogenesis. Genetics 153, 235-250.

Pedersen, K. J. 1959. Cytological studies on the planarian neoblast. Z. Zellforsch. Mikrosk. Anat. 50, 799-817.

Petersen, C. P. \& Reddien, P. W. 2008. Smed-betacatenin-1 is required for anteroposterior blastema polarity in planarian regeneration. Science 319, 327-330.

Reddien, P. W., Bermange, A. L., Kicza, A. M. \& Sánchez Alvarado, A. 2007. BMP signaling regulates the dorsal planarian midline and is needed for asymmetric regeneration. Development 134, 4043-4051.

Reddien, P. W., Bermange, A. L., Murfitt, K. J., Jennings, J. R. \& Sánchez Alvarado, A. 2005a. Identification of genes needed for regeneration, stem cell function, and tissue homeostasis by systematic gene perturbation in planaria. Dev. Cell $\mathbf{8}$, 635-649.

Reddien, P. W., Oviedo, N. J., Jennings, J. R., Jenkin, J. C. \& Sánchez Alvarado, A. 2005b. SMEDWI-2 is a PIWI-like protein that regulates planarian stem cells. Science 310, 1327-1330.

Reddien, P. W. \& Sánchez Alvarado, A. 2004. Fundamentals of planarian regeneration. Annu. Rev. Cell Dev. Biol. 20, 725757.

Rossi, L., Salvetti, A., Batistoni, R., Deri, P. \& Gremigni, V. 2008. Planarians, a tale of stem cells. Cell. Mol. Life Sci. 65, 16-23.

Rossi, L., Salvetti, A., Lena, A., Batistoni, R., Deri, P., Pugliesi, C., Loreti, E. \& Gremigni, V. 2006. DjPiwi-1, a member of the PAZ-Piwi gene family, defines a subpopulation of planarian stem cells. Dev. Genes. Evol. 216, 335-346.
Rossi, L., Salvetti, A., Marincola, F. M., Lena, A., Deri, P., Mannini, L., Batistoni, R., Wang, E. \& Gremigni, V. 2007. Deciphering the molecular machinery of stem cells: a look at the neoblast gene expression profile. Genome Biol. 8, R62.

Salò, E. \& Baguñà, J. 2002. Regeneration in planarians and other worms: new findings, new tools, and new perspectives. J. Exp. Zool. 292, 528-539.

Salvetti, A., Rossi, L., Deri, P. \& Batistoni, R. 2000. An MCM2related gene is expressed in proliferating cells of intact and regenerating planarians. Dev. Dyn. 218, 603-614.

Salvetti, A., Rossi, L., Lena, A., Batistoni, R., Deri, P., Rainaldi, G., Locci, M. T., Evangelista, M. \& Gremigni, V. 2005. DjPum, a homologue of Drosophila Pumilio, is essential to planarian stem cell maintenance. Development 132, 18631874.

Salvetti, A., Rossi, L., Bonuccelli, L., Lena, A., Pugliesi, C., Rainaldi, G., Evangelista, M. \& Gremigni, V. 2009. Adult stem cell plasticity: neoblast repopulation in non-lethally irradiated planarians. Dev. Biol. 328, 305-314.

Sánchez Alvarado, A. 2006. Planarian regeneration: its end is its beginning. Cell 124, 241-245.

Sánchez Alvarado, A. 2007. Stem cells and the Planarian Schmidtea mediterranea. C. R. Biol. 330, 498-503.

Sánchez Alvarado, A. \& Kang, H. 2005. Multicellularity, stem cells, and the neoblasts of the planarian Schmidtea mediterranea. Exp. Cell Res. 306, 299-308.

Sánchez Alvarado, A., Newmark, P. A., Robb, S. M. \& Juste, R. 2002. The Schmidtea mediterranea database as a molecular resource for studying platyhelminthes, stem cells and regeneration. Development 129, 5659-5665.

Sato, K., Hayashi, Y., Ninomiya, Y., Shigenobu, S., Arita, K., Mukai, M. \& Kobayashi, S. 2007. Maternal Nanos represses $\mathrm{hid} / \mathrm{skl}$-dependent apoptosis to maintain the germ line in Drosophila embryos. Proc. Natl Acad. Sci. USA 104, 74557460.

Sato, K., Shibata, N., Orii, H., Amikura, R., Sakurai, T., Agata, K., Kobayashi, S. \& Watanabe, K. 2006. Identification and origin of the germline stem cells as revealed by the expression of nanos-related gene in planarians. Dev. Growth Differ. 48, 615-628.

Seydoux, G. \& Braun, R. E. 2006. Pathway to totipotency: lessons from germ cells. Cell 127, 891-904.

Shibata, N., Umesono, Y., Orii, H., Sakurai, T., Watanabe, K. \& Agata, K. 1999. Expression of vasa(vas)-related genes in germline cells and totipotent somatic stem cells of planarians. Dev. Biol. 206, 73-87.

Shukalyuk, A. I., Golovnina, K. A., Baiborodin, S. I., Gunbin, K. V., Blinov, A. G. \& Isaeva, V. V. 2007. vasa-related genes and their expression in stem cells of colonial parasitic rhizocephalan barnacle Polyascus polygenea (Arthropoda: Crustacea: Cirripedia: Rhizocephala). Cell Biol. Int. 31, 97-108.

Siomi, M. C., Saito, K. \& Siomi, H. 2008. How selfish retrotransposons are silenced in Drosophila germline and somatic cells. FEBS Lett. 582, 2473-2478.

Snee, M. J. \& Macdonald, P. M. 2004. Live imaging of nuage and polar granules: evidence against a precursor-product relationship and a novel role for Oskar in stabilization of polar granule components. J. Cell Sci. 117, 2109-2120.

Solana, J., Lasko, P. \& Romero, R. 2009. Spoltud-1 is a chromatoid body component required for planarian long-term stem cell self-renewal. Dev. Biol. 328, 410-421.

Sugio, M., Takeuchi, K., Kutsuna, J., Tadokoro, R., Takahashi, Y., Yoshida-Noro, C. \& Tochinai, S. 2008. Exploration of embryonic origins of germline stem cells and neoblasts in 
Enchytraeus japonensis (Oligochaeta, Annelida). Gene Expr. Patterns 8, 227-236.

Sunanaga, T., Saito, Y. \& Kawamura, K. 2006. Postembryonic epigenesis of Vasa-positive germ cells from aggregated hemoblasts in the colonial ascidian, Botryllus primigenus. Dev. Growth Differ. 48, 87-100.

Sunanaga, T., Satoh, M. \& Kawamura, K. 2008. The role of Nanos homologue in gametogenesis and blastogenesis with special reference to male germ cell formation in the colonial ascidian, Botryllus primigenus. Dev. Biol. 324, 31-40.

Sunanaga, T., Watanabe, A. \& Kawamura, K. 2007. Involvement of vasa homolog in germline recruitment from coelomic stem cells in budding tunicates. Dev. Genes. Evol. 217, 1-11.

Teshirogi, W. \& Ishida, S., editors. 1987. Biology of Planarians: Foundation, Application and Experiment. Kyoritsu Syuppan, Tokyo.

Umesono, Y. \& Agata, K. 2009. Evolution and regeneration of the planarian central nervous system. Dev. Growth Differ. 51, 185-195.

Umesono, Y., Watanabe, K. \& Agata, K. 1997. A planarian orthopedia homolog is specifically expressed in the branch region of both the mature and regenerating brain. Dev. Growth Differ. 39, 723-727.

Umesono, Y., Watanabe, K. \& Agata, K. 1999. Distinct structural domains in the planarian brain defined by the expression of evolutionarily conserved homeobox genes. Dev. Genes. Evol. 209, 31-39.

Vasileva, A., Tiedau, D., Firooznia, A., Muller-Reichert, T. \& Jessberger, R. 2009. Tdrd6 is required for spermiogenesis, chromatoid body architecture, and regulation of miRNA expression. Curr. Biol. 19, 630-639.

Vessey, J. P., Vaccani, A., Xie, Y., Dahm, R., Karra, D., Kiebler, M. A. \& Macchi, P. 2006. Dendritic localization of the translational repressor Pumilio 2 and its contribution to dendritic stress granules. J. Neurosci. 26, 6496-6508.

Wang, J., Saxe, J. P., Tanaka, T., Chuma, S. \& Lin, H. 2009. Mili interacts with tudor domain-containing protein 1 in regulating spermatogenesis. Curr. Biol. 19, 640-644.

Wang, Y., Zayas, R. M., Guo, T. \& Newmark, P. A. 2007. Nanos function is essential for development and regeneration of planarian germ cells. Proc. Natl Acad. Sci. USA 104, 5901-5906.

Wang, Z. \& Lin, H. 2004. Nanos maintains germline stem cell self-renewal by preventing differentiation. Science $\mathbf{3 0 3}$, 2016-2019.

Webster, P. J., Liang, L., Berg, C. A., Lasko, P. \& Macdonald, P. M. 1997. Translational repressor bruno plays multiple roles in development and is widely conserved. Genes Dev. 11, 2510-2521.

Wickens, M., Goodwin, E. B., Kimble, J., Strickland, S. \& Hentze, M. 2000. Translational control in developmental decisions. In: Translational Control Second Edition ,(ed. M. Mathews), pp. 295-370. Cold Spring Harbor Press, New York.

Wickens, M., Bernstein, D. S., Kimble, J. \& Parker, R. 2002. A PUF family portrait: $3^{\prime} U T R$ regulation as a way of life. Trends Genet. 18, 150-157.

Wilson, A., Laurenti, E., Oser, G., Van Der Wath, R. C., BlancoBose, W., Jaworski, M., Offner, S., Dunant, C. F., Eshkind, L., Bockamp, E., Lio, P., Macdonald, H. R. \& Trumpp, A. 2008. Hematopoietic stem cells reversibly switch from dormancy to self-renewal during homeostasis and repair. Cell 135, 1118-1129.

Wolff, E. \& Dubois, F. 1948. Suy la migration des cellules de régénération chez les planaires. Rev. Suisse Zool. 55, 218227.

Wong, M. D., Jin, Z. \& Xie, T. 2005. Molecular mechanisms of germline stem cell regulation. Annu. Rev. Genet. 39, 173195.

Yazawa, S., Umesono, Y., Hayashi, T., Tarui, H. \& Agata, K. 2009. Planarian Hedgehog/Patched establishes anteriorposterior polarity by regulating Wnt signaling. Proc. Natl Acad. Sci. USA, in press.

Yin, H. \& Lin, H. 2007. An epigenetic activation role of Piwi and a Piwi-associated piRNA in Drosophila melanogaster. Nature 450, 304-308.

Ying, Q. L., Wray, J., Nichols, J., Batlle-Morera, L., Doble, B., Woodgett, J., Cohen, P. \& Smith, A. 2008. The ground state of embryonic stem cell self-renewal. Nature 453, 519523.

Yoon, C., Kawakami, K. \& Hopkins, N. 1997. Zebrafish vasa homologue RNA is localized to the cleavage planes of 2and 4-cell-stage embryos and is expressed in the primordial germ cells. Development 124, 3157-3165.

Yoshida-Kashikawa, M., Shibata, N., Takechi, K. \& Agata, K. 2007. DjCBC-1, a conserved DEAD box RNA helicase of the $\mathrm{RCK} / \mathrm{p} 54 / \mathrm{Me} 31 \mathrm{~B}$ family, is a component of RNA-protein complexes in planarian stem cells and neurons. Dev. Dyn. 236, 3436-3450.

Zayas, R. M., Hernandez, A., Habermann, B., Wang, Y., Stary, J. M. \& Newmark, P. A. 2005. The planarian Schmidtea mediterranea as a model for epigenetic germ cell specification: analysis of ESTs from the hermaphroditic strain. Proc. Natl Acad. Sci. USA 102, 18491-18496. 